\title{
Heterarchy: Exploiting Ambiguity and Organizing Diversity
}

\author{
Heterarquia: Explorando ambiguidades \\ e organizando diversidades
}

DAVID STARK*

RESUMO: Este artigo explora o conceito de heterarquia como uma forma organizacional que é uma alternativa para hierarquias e mercados. As heterarquias são caracterizadas pela responsabilização lateral e por múltiplos princípios organizadores, ou em termos diferentes, pela inteligência distribuída e pela organização da diversidade. Os materiais empíricos são retirados da economia húngara contemporânea, onde as empresas operam em um ambiente de incerteza institucional. Uma análise da estrutura acionária das 200 maiores empresas e dos 25 principais bancos identifica propriedades distintas da rede criadas por vínculos de propriedade interorganizacional. A heterarquia contribui para a flexibilidade; mas o entrelaçamento de múltiplas lógicas de justificação coloca novos problemas de responsabilização.

PALAVRAS-CHAVE: Heterarquia; economia em transição; propriedade privada.

ABSTRACT: This paper explores the concept of heterarchy as an organizational form that is an alternative to hierarchies and markets. Heterarchies are characterized by lateral accountability and multiple organizing principles, or in different terms, by distributed intelligence and the organization of diversity. Empirical materials are drawn from the contemporary Hungarian economy where firms operate in an environment of institutional uncertainty. An analysis of the ownership structure of the largest 200 firms and the top 25 banks identifies distinctive network properties created by ties of inter-organizational ownership. Heterarchy contributes to flexibility; but the interweaving of multiple logics of justification poses new problems of accountability.

KEYWORDS: Heterarchy; transitional economy; private property.

JEL Classification: D23; P26.

\footnotetext{
* Chair and Arnold A. Saltzman Professor of Sociology and International Affairs, Department of Sociology, Columbia University, New York/NY, United States of America. E-mail: dcs36@columbia.edu.
} 


\section{INTRODUCTION}

I have a tin can on my desk that I bought in Budapest in the autumn of 1989. It's considerably smaller than your standard tuna can and extremely light in weight. If you tap your fingernail on it, it gives a hollow ring. But the label, complete with a universal bar code, announces in bold letters that, in fact, it's not empty: "Kommunizmus Utolso Lehelete" — "The Last Breath of Communism".

If I were so inclined, I could take my tin can as a facile metaphor for the transition in Eastern Europe. The last breath of communism marketed by a clever entrepreneur represents the irrepressible urge to truck and barter released by the fresh winds of the free market. Exhale communism, inhale capitalism.

But the conditions under which my tin can was actually manufactured carry another story: It was not produced in the garage workshop of a petty entrepreneur but right in the heart of a state-owned enterprise by a workteam which, since 1982, had been taking advantage of legislation that allowed employees of socialist firms to form "intra-enterprise partnerships". Like many thousands of such intrapreneurial partnerships, this group of thirty workers in a large factory had been running factory equipment on the "off-hours" and on weekends, subcontracting to the parent enterprise and getting orders from outside firms (Stark, 1989).

Similar practices of organizational hedging, resulting in the blurring of public and private and the coexistence of multipie justificatory principies, characterize the bricolage of recombinant processes that are a key feature of the current postsocialist period.

The unopened tin can on my desk thus points to the emptiness of the toggleswitch theory of "market transition" that posits public ownership and state subsidies on one side and private property and markets on the other. And it signals a continuity of recombinatory practices in the reportoire of organizational innovation for actors at the enterprise level.

This paper examines the organizational strategies and the resulting structural features of East European firms in response to the extraordinary uncertainties of systemic transformation following the upheavals of 1989. My starting premise is that postsocialist Eastern Europe is a genuine social laboratory, not simply because researchers can use it to test competing theories, but because people there are actively experimenting with new organizational forms.

Innovation in the postsocialist setting, it would seem, should be directed to adaptation, as firms adapt to the new market environment and national economies adapt to global markets. Without questioning the need for major restructuring, in the opening section of the paper, I argue that preoccupation with short-term adaptation can hinder long term adaptability. I ask whether there are organizational forms that are better configured to learn from the environment. Such organizations would need practices that recognize (re-cognize) new resources in an ongoing reconfiguration of organizational assets.

These challenges are hardly unique to the postsocialist transformations. Therefore, the subsequent section makes explicit my assumption that the term "trans- 
forming economies" applies no less to the societies of North America and Western Europe than to those of Eastern Europe and the former Soviet Union. Firms in both types of economies now face extraordinary uncertainties, caused by the rapidity of technological change or the extreme volatility of markets in the former, and shaped by political and institutional uncertainties in the latter. The response to these uncertainties is an emergent, self-organizing form that I call heterarchy. In elaborating its features, I point to processes of lateral or distributed authority and explore how organizations can benefit from the active rivalry of competing belief systems. Having outlined the characteristics of heterarchical forms, I then focus on the specific challenges facing the postsocialist economies. Once we break with the All-tooprevalent recipes of designer capitalism with its single model of "the capitalist economy", we are able to think about diverse types of capitalism. The collapse of communism and the end of the dichotomous comparison of capitalism versus socialism make us alert to the possibilities of comparing capitalisms (in the plural). As we shall see, that collapse did not leave a tabula rasa. East European is not so much building on the ruins of communism as with the ruins. With these distinctive building blocks they are constructing a distinctively East European capitalism.

\section{THE ORGANIZATION OF DIVERSITY}

Each evening during their hunting season, the Naskapi lndians of the Labrador península determined where they would look for game on the next day's hunt by holding a caribou shoulder bane over the fire. ${ }^{1}$ Examining the smoke deposits on the caribou bane, a shaman read for the hunting party the points of orientation of the next day's search. In this way, the Naskapi introduced a randomizing element to confound a short-term rationality, in which the one best way to find game would seem to have been to look again tomorrow where they had found game today. By following the divergent daily maps of smoke on the caribou bane, they avoided locking in to early successes that, while taking them to game in the short run, would in the long run have depleted the caribou stock in that quadrant and reduced the likelihood of successful hunting. By breaking the link between future courses and past successes, the tradition of shoulder bane reading was an antidote to path dependence in the hunt.

Mainstream notions of the postsocialist "transition" as the replacement of one set of economic institutions by another set of institutions of proven efficiency are plagued by similar problems of short-term rationality that the Naskapi practices mitigated. As the policy variant of "hunt tomorrow where we found game today", neoliberal advisors recommend the adoption of a highly stylized version of the institutions of prices and property that have "worked well in the West". Economic efficiency will be maximized, they argue, only through the rapid and all-encom-

1 This account is drawn from Weick, 1977, p. 45. 
passing implementation of privatization and marketization. I argue here, by contrast, that although such institutional homogenization might foster adaptation in the short run, the consequent loss of institutional diversity will impede adaptability in the long run. Limiting the search for effective institutions and organizational forms to the familiar Western hunting ground of tried and proven arrangements locks in the postsocialist economies to exploiting known territory at the cost of forgetting (or never learning) the skills of exploring for new solutions.

Restated in the language of the new economics of adaptive systems (Arthur, 1994), the problem for any transforming economy is that the very mechanisms that foster allocative efficiency might eventually lock development into a path that is inefficient, viewed dynamically. Within this framework, our attention turns from a preoccupation with adaptation to a concern about adaptability, shifting from the problem of how to improve the immediate "fit" with a new economic environment, to the problem of how to reshape the organizational structure to enhance its ability to respond to unpredictable future changes in the environment.

Sociologists within the tradition of Organizational Ecology have a ready answer to this problem. At the level of the economic system, adaptability is promoted by the diversity of organizations: a system with a greater variety of organizational forms (a more diverse organizational "gene pool") has a higher probability of having in hand some solution that is satisfactory under changed environmental conditions (Hannan, 1986:85). From that viewpoint, the problem of socialism was not only that it lacked a selection mechanism (firms were not allowed to fail), but also that almost all economic resources were locked into one organizational form: the large state-owned enterprise. That form was formidable in achieving industrialization; but lacking capacity for innovation, it failed woefully in the subsequent competition with the West. Similarly, the problem in the current period of transformation is that "success" that is achieved during the transition through forced homogenization towards the privately held corporation might suppress organizational diversity, thereby impeding adaptability in the next round of global competition.

But where do new organizational forms come from? Because I put organizational innovation front and center, I argue that, in addition to the diversity of organizations within a population, adaptability is promoted by the organization of diversity within an enterprise. Organizational diversity is most likely to yield its fullest evolutionary potential when different organizational principies co-exist in an active rivalry within the firm. By rivalry, I do not refer to competing camps and factions, but to co-existing logics and frames of action. The organization of diversity is an active and sustained engagement in which there is more than one way to organize, label, interpret, and evaluate the same or similar activity. Rivalry fosters cross-fertilization. It increases the possibilities of long-term adaptability by better search, "better," not because it is more consistent or elegant or coherent, but precisely because the complexity that it promotes and the lack of simple coherence that it tolerates increase the diversity of options. The challenge of the organization of diversity is to find solutions that promote constructive organizational reflexiv- 
ity, or the ability to redefine and recombine resources. I call the emergent organizational forms with these properties heterarchies.

\section{HETERARCHY}

Heterarchy represents a new mode of organizing that is neither market nor hierarchy: whereas hierarchies involve relations of dependence and markets involve relations of independence, heterarchies involve relations of interdependence. Heterarchy has two fundamental features: lateral accountability and organizational heterogeneity. Heterarchies are about distributed intelligence and the organization of diversity, a pair of concepts that I elaborate below, drawing on studies of collaborative practices in high tech Western firms and my own observations in interactive media firms in New York City. Subsequent sections further specify the applicability of the heterarchy concept in the postsocialist cases.

Heterarchy's twinned features are a response to the increasing complexity of the firm's strategy horizons (Lane and Maxfield, 1996). In relentlessly changing organizations where, at the extreme, there is uncertainty even about what product the firm will be producing in the near future, the strategy horizon of the firm is unpredictable. To cope with these uncertainties, instead of concentrating its resources for strategic planning among a narrow set of senior executives or delegating that function to a specialized department, firms may undergo a radical decentralization in which virtually every unit becomes engaged in innovation. That is, in place of specialized search routines in which some departments are dedicated to exploration, while others are confined to exploiting existing knowledge, the functions of exploration are generalized throughout the organization. The search for new markets, for example, is no longer the sole province of the marketing department, if units responsible for purchase and supply are also scouting the possibilities for qualitatively new inputs that can open up new product lines.

These developments increase interdependencies between divisions, departments, and work teams within the firm. But because of the greater complexity of these feedback loops, coordination cannot be engineered, controlled, or managed hierarchically. The results of interdependence are to increase the autonomy of work units from central management. Yet at the same time, more complex interdependence heightens the need for fine-grained coordination across the increasingly autonomous units.

These pressures are magnified by dramatic changes in the sequencing of activities within production relations. As product cycles shorten from years to months, the race to new markets calls into question the strict sequencing of design and execution. Because of strong first-mover advantages, in which the first actor to introduce a new product (especially one that establishes a new industry standard), captures inordinate market share by reaping increasing returns, firms that wait to begin production until design is completed will be penalized in competition. Like the production of " $\mathrm{B}$ movies" in which filming begins before the script is com- 
pleted, successful strategies integrate conception and execution, with significant aspects of the production process beginning even before design is finalized.

Production relations are even more radically altered in processes analyzed by Sabel and Dorf (1998) as simultaneous engineering. Conventional design is sequential, with subsystems that are presumed to be central designed in detail first, setting the boundary conditions for the design of lower-ranking components. In simultaneous engineering, by contrast, separate project teams develop all the subsystems concurrently. In such concurrent design, the various project teams engage in an ongoing mutual monitoring, as innovations produce multiple, sometimes competing, proposals for improving the overall design.

Under circumstances of simultaneous engineering where the very parameters of a project are subject to deliberation and change across units, authority is no longer delegated vertically but rather emerges laterally. As one symptom of these changes, managers socialized in an earlier regime frequently express their puzzlement toresearchers: “There's one thing I can't figure out. Who's my boss?". Under conditions of distributed authority, managers might still "report to" their superiors; but increasingly, they are accountable to other work teams. Success at simultaneous engineering thus depends on learning by mutual monitoring.

The interdependencies that result from attempts to cope with rugged fitness landscapes are only inadequately captured in concepts of "matrix organizations" or in the fads such as treating the firm as a set of "internal markets" according to which every unit should regard every other unit in the firm as its "customers". These conceptions are inadequate because they take the boundaries of the firm and the boundaries of its internal units as given parameters.

As Walter Powell (1996) and others show, the boundaries of the firm, especially those in fast-breaking sectors, are criss-crossed by dense ties of interlocking ownership (Kogut, et al., 1992) and complex patterns of strategic alliances. Where the environment is most volatile and uncertain, the real unit of economic action is increasingly not the isolated firm but networks of firms. As with the networks linking mental representations and physical artifacts in "distributed cognition" (Hutchins, 1995), networks of strategic alliances create opportunities for distributed intelligence across the boundaries of firms.

The challenge of the modern firm, whether it be a postsocialist firm coping with the uncertainties of system change or a digital technologies firm coping with umpredictable strategy horizons, is the challenge of building organizations that are capable of learning. Flexibility requires an ability to redefine and recombine assets: in short, a pragmatic reflexivity.

This capacity for self-redefinition is grounded in the organizational heterogeneity that characterizes heterarchies. Heterarchies are complex adaptive systems because they interweave a multiplicity of organizing principies. The new organizational forms are heterarchical not only because they have flattened hierarchy, but also because they are the sites of competing and coexisting value systems. The greater interdependence of increasingly autonomous work teams results in a proliferation of performance criteria. Distributed authority not only implies that units 
will be accountable to each other, but also that each will be held to accountings in multiple registers. The challenge of a new media firm, for example, is to create a sufficiently common culture to facilitate communication among the designers, business strategists, and technologists that make up interdisciplinary teams - without suppressing the distinctive identities of each. ${ }^{2}$ A robust, lateral collaboration flattens hierarchy without flattening diversity. Heterarchies create wealth by inviting more than one way of evaluating worth.

\section{MAKING THE BEST OF ONE'S RESOURCES AS THE NEXT-BEST WAY TO CAPITALISM}

While managers in advanced sectors are coping with volatile markets, rapid technological change, and the challenges of simultaneous engineering, policy makers in the postsocialist world must cope with a set of different, but equally complex, strategy horizons.

The restructuring of the postsocialist firm is taking place in the context of a dual transformation of politics and property: The twinned processes of democratization and privatization accompanying the collapse of Communism have simultaneously extended citizenship rights and property rights. ${ }^{3}$ Indeed, this simultaneity marks the specificity of postsocialism. Several East Asian societies, for example, have embarked on the course of democratization, but, unlike Eastern Europe and the former Soviet Union, only after economic reforms had already opened their economies to world markets in a period of an expanding global economy. In Latin America, economic liberalization and political democratization were undertaken at the same time, but unlike Eastern Europe, economic reforms did not involve a fundamental transformation of property regimes.

Adept at mitigating the bureaucratic uncertainties of central planning, managers of the formerly socialist firms suddenly had to cope with an imposing set of uncertainties of a very different character: Trade relations would have to be reoriented with the collapse of the old Soviet-directed COMECON-CMEA (Council of Mutual Economic Assistance) trading partners; suppliers and customers were no longer hierarchically imposed but would now be regulated by contracts (of untested and therefore uncertain enforcement); and new legislation regulating ac-

\footnotetext{
${ }^{2}$ A young business strategist in a leading new media consulting firm in Silicon Alley grasped the problem intuitively. When I asked whether he can speak the language of the designers and technologists on his project teams, he responded that he frequently does. But then he paused for a moment and added, "But I don't always does. If I always talked to the technologist on his own terms, then he would never understand $m e "$.

${ }^{3}$ The simultaneous emergence of newly propertied classes and newly enfranchished subordinate groups
poses the central postsocialist challenge of how to restructure economies when those who perceive their
interests to be threatened by economic change have the capacity to replace political incumbants. For a
comparative study of this problem in four East Central European countries, see Stark and Bruszt 1998 .
} 
counting, bankruptcy, and corporate governance brought strange new professionals (accountants, lawyers, and Boards of Directors) right into the heart of the firm. These new uncertainties in the firm's business environment, moreover, were compounded by new political uncertainties when startling rates of unemployment occurred among workers/citizens recently empowered with the capacity to replace political incumbants. Policy makers and enterprise decision makers thus confronted a complex and unfamiliar strategy horizon. How should they reorganize economies and restructure firms in the face of these extraordinary uncertainties?

For many Western policy advisors who flew into the region (often with little knowledge of its peculiarities), the answers were straightforward, and two positions quickly dominated the debate. On the one side was the message of the neoliberais: the best way to restructure is to use strong markets. Markets, they argued, were not only the goals but also the means. Rapid privatization, trade and price liberalization, strict bankruptcy laws, and an end to government subsidies were key elements of their policy prescriptions. But the depth and rapidity of economic recession in the aftermath of 1989 dampened enthusiasm for the neoliberal agenda, and An alternative, neostatist, position entered the debate arguing that the neoliberal strategy confuses goals and means. To create markets, one cannot simply rely on markets. Strengthening the market requires strong states.

The choice seemed clear: strong markets versus strong states. The problem, however, was that the societies of the postsocialist world historically lack both developed markets and coherent states. The non-existing starting points of the neoliberals and the neostatists recall the joke in which an lrishman in the far countryside is asked, "What's the best way to get to Dublin?". He thinks for a minute, and responds, "Don't start from here".

The irony of the answer would not be lost on East Europeans, for they are all too acutely aware that the best ways to get to capitalism started somewhere else. But those options are not available to our contemporary travelling companions. Accordingly, this essay adopts a different analytic starting point, the pragmatic, self-organizing starting point of the East Europeans themselves who, in place of the question "What is the best way to get to capitalism?" must ask, "How do we get there from here?". In place of the therapies, recipes, formulas, and blueprints of designer capitalism, postsocialist firms have had to adopt a different strategy: precluded from the best ways to get to capitalism, they are making the best of what they have.

With what institutional resources have they embarked? Postsocialist societies lack strong markets and strong states, but they have decades of experience with strong networks under socialism. These associative ties of reciprocity were unintended consequences of the attempt to "scientifically manage" an entire national economy: at the shop-floor level, shortages and supply bottlenecks led to bargaining between supervisors and informal groups; at the level of the shadow economy of gray market activities, the distortions of central planning reproduced the conditions for networks of predominantly part-time entrepreneurs; and at the managerial level, the task of meeting plan targets produced dense networks of informal ties that cut across enterprises and local organizations. 
Some of these network ties dissipate in the transforming postsocialist economic environment; others are strengthened as firms, individuals, banks, local governments, and other economic actors adopt coping strategies to survive (not all of them legal, and in some countries, many of them corrupt); and still others emerge anew as these same actors search for new customers and suppliers, new sources of credit and revenues, and new strategic allies. The existence of parallel structures in the informal and interfirm networks that "got the job clone" under socialism means that instead of an institutional vacuum, we find routines and practices that can become assets, resources, and the basis for credible commitments and coordinated actions. In short, associative ties build new forms of association as the "ties that bind" shape binding agreements.

The resulting new property forms blur the boundaries of public and private, erode the organizational boundaries of the firms, and multiply the operative evaluating principles with which the firm justifies access to resources. I refer to this ensemble of characteristics as recombinant property.

Recombinant property is a form of organizational hedging in which actors respond to uncertainty in the organizational environment by diversifying their assets, and redefining and recombining resources. $\ln$ its extreme form, it is an attempt to hold and label resources that can be justified or assessed by more than one standard of evaluation. The overlap of a multiplicity of property regimes in the postsocialist circumstances does not simply mean that multiple owners are making different claims on the resources of the firm, but rather that the multiple regimes provide multiple opportunities for the firm to make claims for resources. "Asset diversification" in such cases differs markedly from that of the mutual fund portfolio manager, whose strategy can be captured in the algorithm that expresses optimizing preferences across risk functions, short-term revenues, long-term growth, and the like. By contrast, the recombinant strategies in the postsocialist cases are practices that seek to manage asset ambiguity. Under circumstances of asset interdependence, some assets are most valuable precisely where property claims are least clarified; thus, under circumstances where multiple legitimating principles are at play, actors gain advantage if they can exploit the ambiguity of justifications for claims. In this highly uncertain environment, therefore, enterprise survival can depend on skills that make assets of ambiguity.

\section{RECOMBINANT PRACTICES IN HUNGARY}

Immediately following the first free elections in Spring 1990, the new democratic government of Hungary announced an ambitious program of privatization. Because this was intended to be a state-directed course of property transformation, the government created a large bureaucratic agency, the State Property Agency (SPA), responsible for every aspect of privatizing the productive assets of the Hungarian economy, some ninety per cent of which had been held by the state. From its inception, the SPA adopted the official policy that privatization would be conducted on 
a strictly case-by-case, firm-by-firm basis. SPA policy never treated assets as interdependent across firms, or considered that firms might be broken up and their assets regrouped by economic agents with local knowledge of constraints and opportunities. Instead, it adopted a role as Big Broker, attempting to match buyers to firms, and it sought to legitimate its activities externally by emphasizing the bottom line: revenues brought into the state treasury from the eventual sale of individual firms.

Enterprise directors thought otherwise. While bureaucratic administrators in the agency debated the merits of auctions versus public offerings, and transaction officers in the agency scrambled to acquire some familiarity with the dozens of firms assigned to their supervision, enterprise management took advantage of several pieces of legislation to launch their own strategies of property transformation.

Although we typically think about owners acquiring firms, the peculiar circumstances of the economic transformation in Eastern Europe has placed extraordinary political and economic pressure on postsocialist firms to acquire owners. They do so, moreover, under circumstances in which the demand for owners greatly exceeds the supply. On one side, the demand for owners is high: the postsocialist firm is searching for new owners at precisely the same time that thousands of other firms are doing the same. On the other side, the supply of owners with adequate capital and interest is relatively low: the domestic population has savings that equal only a fraction of the value of the assets of the state-owned enterprises, while there are only so many interested foreign buyers. Politically compelled to find owners to adjust to the new political setting, and organizationally compelled to find owner-allies to address the challenges of the new economic environment, the postsocialist firms find each other. That is, they acquire shares in other firms and they make arrangements for other enterprises to become their new shareholders. The results are dense networks of interlocking ownership ties that extend through and across branches and sectors of the economy, especially among the very largest enterprises and banks.

\section{Network properties}

To assess the prevalence of such inter-enterprise ownership, we compiled a data set on the ownership structure of the largest 200 Hungarian corporations (ranked by sales). These firms compose the "Top 200" on the listing of Figyelo, a leading Hungarian business weekly. Like their Fortune 500 counterparts in the United States, the "Figyelo 200" firms are major players in the Hungarian economy, employing an estimated 21 percent of the labor force and accounting for 37 percent of total net sales and 42 percent of export revenues. The data also include the top 25 Hungarian banks (ranked by assets). Ownership data were obtained in the spring of 1994 and updated in the spring of 1996, gathered directly from the Hungarian Courts of Registry where corporate files contain complete lists of the company's owners as of the most recent shareholders' meeting. Following the convention in the literature of East Asian business groups, analysis is restricted to the top 20 owners of each corporation.

Who holds the shares of these largest enterprises and banks? Through its property holding agencies, the state remains the most prominent owner. It is the sole and exclusive owner of 16.4 percent of these firms, and keeps its hand in as one of 
the top 20 owners in 44.4 percent of the largest corporations and banks in 1996. Although whittled down, the state is not withering away. Only five companies (2.0 percent) in this population were owned exclusively by private individuals in 1996 . Even by the least restrictive criterion - the presence of even one individual private investor among a company's major owners - individual private ownership cannot be seen as ascendant: in 1994, 102 individuals in the data set held ownership stakes in 8.5 percent of these largest enterprises and banks. In 1996, these figures actually declined, with only 61 individuals appearing among the twenty major owners of only 7.3 percent of the units in our population.

Inter-corporate ownership, on the other hand, is increasing as the percentage of units with at least one corporate owner rose from 66.3 percent to 77.6 percent in 1996. Most notably, the number of units in which all the top twenty owners are other corporations increased from 35.6 percent to 40.2 percent. Many of these owners are themselves the largest enterprises and banks, the very firms for which we gathered the ownership data.

\section{Property as an emergent property}

Beyond confirming the prevalence of such inter-enterprise ownership, the data also allow us to identify the links among these large enterprises. These ties are dense and extensive, and they yield numerous networks of interconnected holdings. Figure 1 presents a typical network formed through these ownership ties. The numbered nodes represent specific firms or banks, and the lines indicate an ownership connection between them.

Figure 1: A Hungarian Inter-firm Network

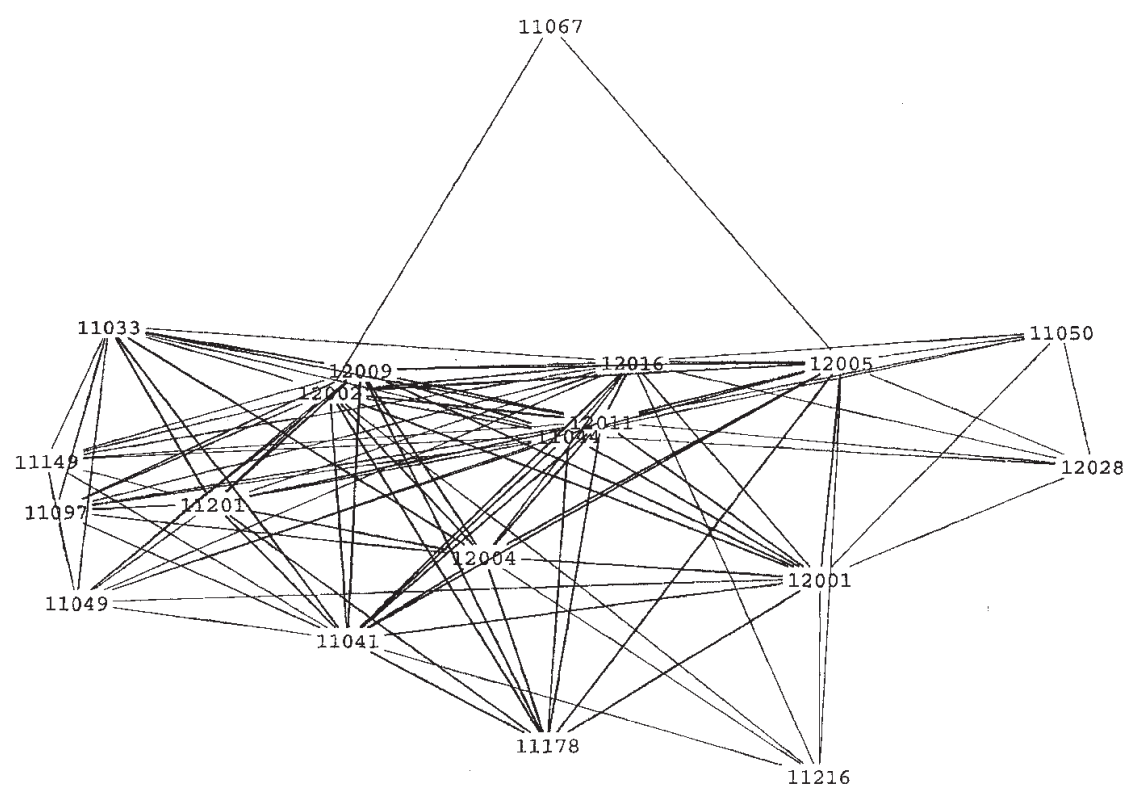


Direct ties among the largest firms, however, are only the most immediate way to identify relational properties in the field of interacting strategies. For, in addition to knowing the direct ties between two firms (e.g., Company A is a major shareholder of Bank B) we can also identify the patterns formed by their mutual shareholdings even when two firms are not themselves directly tied (e.g., Enterprises C, $\mathrm{D}, \mathrm{E}$, and $\mathrm{F}$ share a relation by virtue of the tie through Bank $\mathrm{X}$, which is a major shareholder in each; or Bank X and Bank Z are "linked" by their mutual ownership in Enterprise M).

Incorporating this more complete ensemble of ties allows us to probe a concept that network analysts refer to as "structural similarity". To take a homely example, if all your friends are my friends, we are structurally similar even if we do not know each other. The notion of structural similarity gives a more robust view of the overall properties of the field because it provides a richer interpretation of proximity in a structural space: we might be indifferent to knowing precisely who is friends with whom if our question is to ask, who runs in the same social circles. The strategist for a biotechnology firm who is trying to anticipate the next moves of the competition might well want to know which firms tend to license identical patents, even when the competitors do not directly license patents from each other (e.g., where Ns competitors B and C do not license each other's patents, but both tend to license patents from $\mathrm{D}, \mathrm{E}$, and $\mathrm{F}$ ).

For our dataset, two companies are structurally similar if their overall sets of relations, compared to all the other firms in the dataset — that is, to all the possible owners as well as to all the units that can be owned - are nearly alike. We use a clustering algorithm to identify the major business groupings of the Hungarian economy formed through inter-enterprise ties. The results are depicted in Figure 2.

Figure 2: Business Groups in the Hungarian Economy

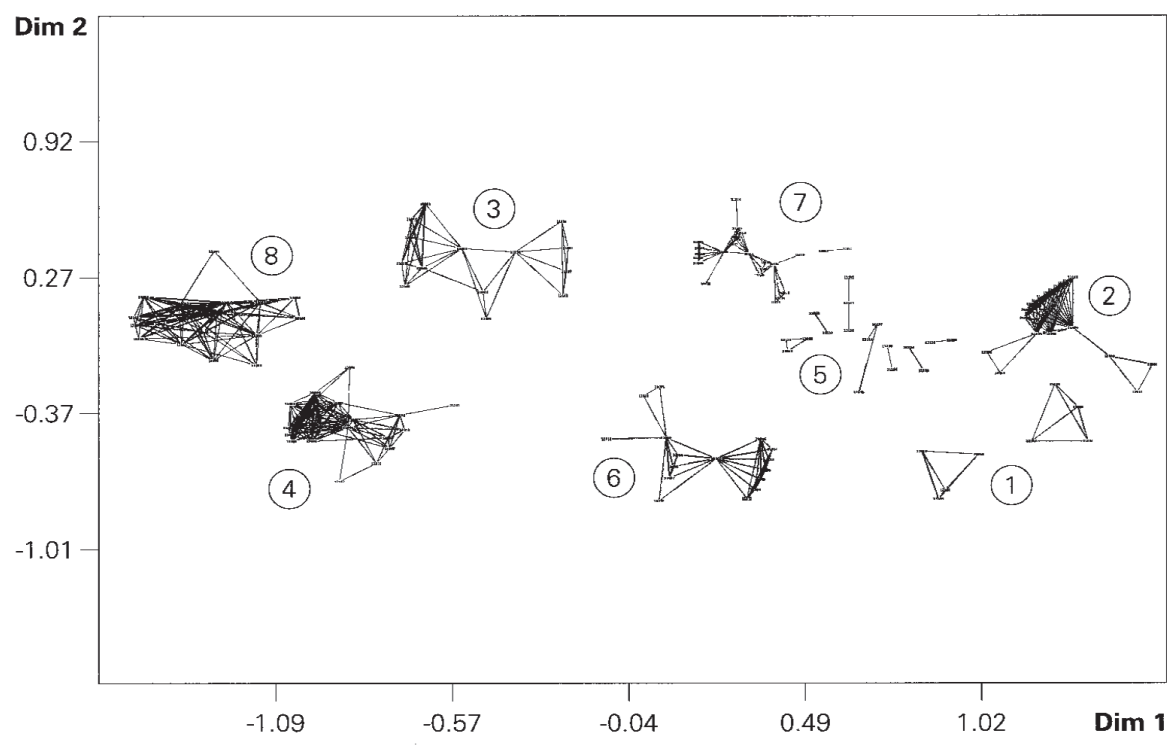


Whereas Figure 1 represents a discrete network formed through direct ties, Figure 2 takes a broader view to show the various "teams" and their proximity to each other in the whole field. To understand the representation, as a first approximation, think of each firm as having a portfolio of holdings (the other companies in which it holds shares) and as having a portfolio of owners (its shareholders). The eight business groupings shown in Figure 2 result from the intersections of these twinned portfolios. Then think again, but this time instead of taking the individual firm as the unit of analysis, take the relatively discrete network of firms as the unit. That is, think about property as the network properties of a group of firms, and about a portfolio not as a feature of a single firm but as a property of the network. Once we think of each network as a distinctive portfolio, the very unit of strategic action changes. Firms do not disappear in the story, for it is their individual actions of shareholding, of making and breaking ties, that drive the process. But the whole is more than the sum of the parts. Or, more accurately, simply summing the individual portfolios yields the descriptive statistics of percentages held by this or that type of owner, while aggregating their relational properties yields new orders of phenomena above the constituent units. Restated in the language of Complex Adaptive Systems: property has emergent properties. The networks represented in Figure 2 are not conglomerates or holding companies. They were not built by design, but emerged from the interacting ownership strategies of hundreds of enterprises. As examples of distributed intelligence, these emergent networks display a feature of heterarchy. A Hungarian business network is not a megafirm, it has no single decision-making center, and unlike the Japanese keiretsu, it has no distinctive emblem or flag though which affiliate members signal their collective identity. Too extensive to be called a single strategic alliance, it is a complex network of intersecting alliances.

More detailed analysis of the discrete networks indicates that their strategies of portfolio management are distinctive (for details, see Stark, Kemeny, and Breiger, 1998). ln some, structure derives from the role of key banks that own shares in manufacturing enterprises. In others, banks are also prominent, not as owners, but as mutually owned by the affiliated enterprises. Some of the networks span branches and sectors. Others group firms in particular sectors. Network 3, for example, contains the major bus, railroad, trucking, and airline firms, linked with three banks and six foreign trade companies; and the elongated configuration of Network 7 corresponds to its character as an integrated commodity chain that links firms in petroleum, petrochemicals, chemicals, and pharmaceuticals.

But despite the distinctive shapes of their network properties, all of these major business groupings share an important feature of heterarchies: common to each is a strategy of combining heterogeneous resources. Each business network attempts a strategy of portfolio management that diversifies across the resources (and constraints) that derive from ownership by state agencies as well as from the new resources of multinational enterprises and other foreign investors. None is exclusively public nor predominantly private. Each regroups assets that allow it to operate across the playing field. All are poised to take advantage of continuing subsidies, exemptions from tariff restrictions, and state largesse in forgiving inher- 
ited debt, while benefiting from new sources of capital, access to markets, and technology transfers. In the postsocialist context, networked property is recombinant property.

\section{Risk spreading and risk taking}

These inter-enterprise networks are an important means of spreading risk in an uncertain environment. Firms in the postsocialist transformational crisis are like mountain climbers assaulting a treacherous face, and interorganizational networks are the safety ropes lashing them together. Such risk-spreading, moreover, can be a basis for risk-taking. Extraordinarily high uncertainties of the kind we see now in the postsocialist economies can lead to low levels of investment with perverse strategic complementarities (as when firms forgo investments because they expect a sluggish economy based on the Jack of investments by others). By mitigating disinclinations to invest, risk-spreading within affiliative networks might be one means to break out of otherwise low-level equilibrium traps.

This relationship between risk-spreading and risk-taking suggests that it would be premature in the postsocialist context to impose a rigid dichotomy between strategies of survival and strategies of innovation. Above all, we should not assume that firms will necessarily innovate even when survival seems to demand it, as if necessity in itself creiltes the conditions for innovation. Recent studies (e.g., Miner, Amburgey and Stearns, 1990) provide strong theoretical arguments that firms are more likely to undertake the risky business of innovation (exposing themselves to the "liabilities of newness" by engaging in unfamiliar routines), not when they are pushed to the wall, but when they are buffered from the immediate effects of selection mechanisms. They further demonstrate that interorganizational networks provide this buffering by producing the requisite organizational slack through which enterprises can find the available resources that make it possible to innovate. Thus, these studies suggest circumstances in which the simple imperative, "Innovate in order to survive" is reasonably reversed: "Survive in order to innovate".

These insights have been independently confirmed in a recent study by Ickes, Ryterman, and Tenev (1995) who demonstrate, on the basis of rich survey data on Russian firms, that enterprises that are linked in inter-enterprise networks are more likely to engage in various forms of economic restructuring than similar firms that are not so linked. That finding, moreover, is robust: purely private enterprises are not more likely to undertake restructuring than firms in state ownership, or mixed property arrangements embedded in inter-enterprise networks. A related study on innovation in the Hungarian economy (Tamas, 1993) found that firms with the organizational hedging strategy of "mixed" (public and private) ownership were more likely than purely private or purely state-owned firms to have innovated by introducing new technologies or bringing out new products. ln short, when we abandon the forced dichotomy of survival versus innovation, we can see that there are circumstances in which survival strategies can be the prelude to strategies of innovation. 


\section{Accounts}

In the highly uncertain organizational environment that is the postsocialist economy, relatively few actors (apart from institutional designers such as IMF advisors or local policy-makers in Finance Ministries) set out with the aim to create a market economy. Many indeed would welcome such an outcome, but their immediate goals are more pragmatic: at best to thrive, at least to survive. And so they strive to use whatever resources are available. As they do so, they maneuver not only through an ecology of organizations but also through a complex ecology of ordering principies. To analyze this process, I exploit a notion of accounts. Etymologically rich, the term simultaneously connotes bookkeeping and narration. Both dimensions entail evaluative judgments, and each implies the other: Accountants prepare story lines according to established formulae, and in the accountings of a good storyteller we know what counts. In everyday life, we are all bookkeepers and storytellers. We keep accounts and we give accounts, and most importantly, we can be called to account for our actions. It is always within accounts that we "size up the situation," for not every form of worth can be made to apply and not every asset is in a form mobilizable for a given situation (Stark 1990). We evaluate the situation by maneuvering to use scales that measure some types of worth and not others, thereby acting to validate

some accounts and discredit others (Boltanski and Thevenot 1991). The multiple accounts voiced in Hungarian heterarchies respond to and exploit the fundamental, though diffused, uncertainty about the organizational environment. In transforming economies, firms have to worry not simply about whether there is demand for their products, or about the rate of return on their investment, or about the level of profitability, but also about the very principle of selection itself. Thus, the question is not only "Will I survive the market test?" but also, under what conditions is proof of worth on market principies neither sufficient nor necessary to survive? Because there are multiply operative, mutually coexistent principies of justification according to which you may be called on to give accounts of your actions, you cannot be sure what counts. By what proof and according to which principies of justification are you worthy to steward a given set of resources? Because of this uncertainty, actors will seek to diversify their assets: to hold resources in multiple accounts.

This ability to glide among principies and to produce multiple accountings is an organizational hedging. It differs, however, from the kind of hedging to minimize risk exposure that we would find within a purely market logic as, for example, when the shopkeeper who sells swimwear and sun lotion also devotes some floor space to umbrellas. Instead of acting within a single regime of evaluation, this is organizational hedging that crosses and combines disparate evaluative principies. Recombinant property is a particular kind of portfolio management. It is an attempt to have a resource that can be justified or assessed by more than one standard of measure (as, for example, the rabbit breeder whose roadside stand advertises "Pets 
and Meat" in the documentary film Roger and Me). In managing one's portfolio of justifications, one starts from the axiom: diversify your accounts.

The adroit recombinant agent in the transforming economies of East Central Europe diversifies holdings in response to fundamental uncertainties about what can constitute a resource. Under conditions not simply of market uncertainty but of organizational uncertainty, there can be multiple (and intertwined) strategies for survival, based in some cases on profitability but in others on eligibility. Your success is judged, and the resources placed at your disposal determined, sometimes by your market share, and sometimes by the number of workers you employ in a region; sometimes by your price-earnings ratio and sometimes by your "strategic importance"; and, when even the absolute size of your lasses can be transformed into an asset yielding an income stream, you might be wise to diversify your portfolio, to be able to shift your accounts, to be equally skilled in applying for loans as in applying for job creation subsidies, to have a multilingual command of the grammar of credit-worthiness and the syntax of debt forgiveness. To hold recombinant property is to have such a diversified portfolio.

To gain room for maneuver, actors court and even create ambiguity. They measure in multiple units, they speak in many Tongues. ln so doing, they produce the heterarchical discourse of worth that is postsocialism. We can hear that polyphonic chorus in the diverse ways that Hungarian firms have justified their claims for participation in a debt-relief program established by the government after its earlier programs had precipitated a near-collapse of the financial system. ${ }^{4}$ The following litany of justifications are stylized versions of claims encountered in discussions with bankers, property agency officials, and enterprise directors:

- Our firm should be included in the debt relief program because we will forgive our debtors. ${ }^{5}$

- Our firm should be included in the debt relief program because we are truly creditworthy. ${ }^{6}$

- Because we employ thousands.

- Because our suppliers depend on us for a market.

- Because we are in your election district.

- Because our customers depend on our product inputs.

- Because we can then be privatized.

- Because we can never be privatized.

- Because we took big risks.

\footnotetext{
4 Those policies are described in Stark (1996). The following chorus is drawn from the same article.

${ }^{5}$ I.e., our firm occupies a strategic place in a network of inter-enterprise debt.

${ }^{6}$ I.e., if our liabilities are separated from our assets, we will again be eligible for more bank financing. Similar translations could be provided for each of the following justifications.
} 
- Because we were prudent and did not take risks.

- Because we were subject to planning in the past.

- Because we have a plan for the future.

- Because we export to the West.

- Because we export to the East.

- Because our product has been awarded an International Standards Quality Control Certificate.

- Because our product is part of the Hungarian national heritage.

- Because we are an employee buy-out.

- Because we are a management buy-in.

- Because we are partly state-owned.

- Because we are partly privately-held.

- Because our creditors drove us into bankruptcy when they loaned to us at higher than market rates to artificially raise bank profits in order to pay dividends into a state treasury whose coffers had dwindled when corporations like ourselves effectively stopped paying taxes.

And so we must ask, into whose account and by which account will debt forgiveness flow? Or, in such a situation, is anyone accountable? By making assets of ambiguity, Hungarian managers gain flexibility. But is this acute flexibility an unmixed blessing? I think not. In this I depart from the now standard formula in which the economic sociologist enumerates the problems created by markets, recounts the problems created by hierarchy, and then delineates the problems resolved by the new organizational forms (hybrids, networks, flexible specializations, etc.). But as the best practioners are already recognizing, the new organizational forms also create new problems. The same opportunistic blurring of boundaries that leads to a recombination of assets and a decomposition and reintegration of organizations also bears a social cost: it erodes (or, in the postsocialist case, retards) accountability. The problem with the peculiarly diversified portfolios of the new heterarchies is that actors can all too often easily and almost imperceptibly switch among the various positions they hold simultaneously in the coexisting moral economies. To be accountable according to many different principies becomes a means to be accountable to none. Unless we are willing to posit "flexibility" as an over-riding value and a metalegitimating principle, we cannot escape the challenge that postsocialism poses, not uniquely but acutely, for our epoch: if heterarchies are viable economic agents of permanently ongoing restructuring, how can we make them accountable?

\section{CONCLUSION}

Several years after I bought the tin can that we saw in my lntroduction, a friend in Budapest told me about a board game he had played as a child during the social- 
ist period. Prior to the Second World War, Hungarians had played Monopoly, known there as Kapitaly. But the competitive game of capitalism was banned by communist authorities, who substituted another board game, Gazdalkozde Okosan!, or "Economize Wisely!". In this goulash communist version of political correctness the goal was to get a job, open a savings account, and acquire and furnish an apartment. My friend was too young to have a Kapitaly board, but his older cousins from another part of the country knew the banned game and taught him the basic rules. You didn't need to be a nine-year old dissident to see that Monopoly was the more exciting game. And so they turned over the socialist board game, drew out the Kapitaly playing field from Start to Boardwalk on the reverse side, and began to play Monopoly — using the cards and pieces from Economize Wisely. But with the details of the rules unclear and with the memories of the older cousins fading, the bricolaged game developed its own dynamics, stimulated by the cards and pieces from the "other side." Why, for example, be satisfied with simple houses and hotels when you could have furniture as well? And under what configurations of play would a Prize of Socialist Labor be grounds for releasing you from or sending you to Jail? ${ }^{7}$

The notion of playing capitalism with communist pieces strikes me as an apt metaphor for the postsocialist condition. The political upheavals of 1989 in Eastern Europe and 1991 in Russia turned the world upside down. Misled by an apparent tabla rasa, the IMF and Western advisors issued instructions for the new "rules of the game," but it was played with the institutional remnants of the past that, by limiting some moves and facilitating other strategies, gave rise to multiple systems of accounting. Firms responded to these uncertainties by exploiting the uncertainties. The results are, as we saw, the networks linking statist institutions and "privatized" firms in the Czech Republic and the multiple legitimating claims in the polyphonic chorus of Hungarian debt forgiveness.

But, if our Hungarian chorus sounds strange and exotic, it should be so only upon first encounter. For, although that litany expresses multiple accounting principies in an especially acute form, the notion of coexisting evaluative frameworks is far from foreign in the highly uncertain environments of advanced sectors in the west. If the successful Hungarian manager must be as skilled in the language of debt forgiveness as in the language of negotiating with a prospective multinational partner, the CEO of a start-up firm in biotechnology might well survive only if she is as adept in writing grant proposals to federal agencies as she is in making the pitch to prospective venture capitalists. We need not travel to Eastern Europe to encounter difficulties in assessing the value of firms, when stories of the difficulties of evaluating Internet stocks fill the front pages of our newspapers. We are not strang-

\footnotetext{
7 The story itself was related while we watched my children playing their own hybrid version: having left the houses and hotels of their Monopoly set at a friend's house, they had started to use Lego building blocks (much preferred to the Monopoly pieces even after returned) to construct ever more elaborate structures in a game whose rules evolved away from bankrupting one's opponents and towards attracting customers to the plastic skyscrapers that towered over the Monopoly plain.
} 
ers to the problems of parsing public and private, for we need look no further than the complex proprietary arrangements between private firms and public universities in the fields of computer science, biotechnology, new media, and engineering. And the search for a mutually comprehensible language across the cultures of science, politics, and business in the human genome project offers no less acute problems of public and private accountability.

To write of "problems" is not to denounce the creative organizational solutions that are evolving in all of the areas mentioned above. On the contrary, it calls attention to the fact that the most sophisticated, dynamic, and path-breaking sectors are likely to be arenas where public and private are closely intertwined.

Complexity, in the field of organizations, is the interweaving of diverse evaluative principies. These principies can be those of public and private accountings, but they can also be the diverse worldviews of different professional identities, each with its own distinctive ways of measuring value and selecting what counts. The assets of the firm are adaptively increased when there are multiple measures of what constitutes an asset. Value is amplified precisely because values are not shared. The heterarchical organization of diversity is sometimes discordant. But to still that noisy clash by the ascendancy of only one accounting would be to destroy the diversity of organizing principies that is the basis of adaptability.

\section{REFERENCES}

ARTHUR, W. Brian (1994) Increasing returns and path dependence in the economy. Ann Arbor: University of Michigan Press.

BOLTANSKI, Luc and Laurent THEVENOT (1991). De la justification: Les economies de la grandeur. Paris: Gallimard.

HANNAN, Michael T. (1986) "Uncertainty, Diversity, and Organizational Change.” Pp. 73-94 in Behavioral and social sciences: fifty years of discovery: in commemoration of the fiftieth anniversary of the "Ogburn report", edited by Neil J. Smelser and Dean R. Gerstein. Washington, D.C.: National Academy Press.

HUTCHINS, Edwin (1995) Cognition in the Wild. Cambridge, Mass: MIT Press.

ICKES, Barry W., Randi RYTERMAN, and Stoyan TENEV (1995) "On Your Marx, Get Set, Go: The Role of Competition in Enterprise Adjustment.” Unpublished Manuscript, The World Bank, September.

KOGUT, Bruce, Weijan SHAN, and Gordon WALKER (1992) “The Make-or-Cooperate Decision in the Context of an Industry Network.” Pp. 348-65 in Networks and Organizations, edited by Nitin Nohira and Robert G. Eccles. Cambridge, MA: Harvard Business School Press.

LANE, David, and Robert MAXFIELD (1996) "Strategy under complexity: Fostering generative relationships." Long Range Planning vol. 29(2):215-31.

MINER, Anne, Terry L. AMBURGEY, and Timothy M. STEARNS (1990) "Interorganizational Linkages and Population Dynamics: Buffering and Transformational Shields." Administrative Science Quarterly 35:689-713.

POWELL, Walter W. (1996). “Inter-organizational Collaboration in the Biotechnology Industry.” Journal of Institutional and Theoretical Economics 152:197-215.

SABEL, Charles F., and Michael C. DORF (1998) «A Constitution of Democratic Experimentalism» Columbia Law Review 98(2): 267-529.

STARK, David (1989) “Coexisting Organizational Forms in Hungary’s Emerging Mixed Economy.” Pp. 
137-168 in Remaking the Economic Institutions of Socialism: China and Eastern Europe, edited by Victor Nee and David Stark. Stanford: Stanford University Press.

(1990) "La valeur du travai! et sa rétribution en Hongrie." Actes de la recherche en sciences sociales (Paris)\# 85, November: 3-19. Available in English as "Work, Worth, andJustice." www. sociology.columbia.edu/faculty/stark/worth.

(1996) "Recombinam Property in East European Capitalism." American Journal of Sociology 101: 993-110.

STARK, David and László BRUSZT (1998) Postsocialist Pathways: Transforming Politics and Property in East Central Europe. New York and London: Cambridge University Press.

STARK, David, Szabolcs KEMENY, and Ronald BREIGER (1998) "Post-Socialist Portfolios: Network Strategies in the Shadow of the State." Paper presented at the 1998 annual meeting of the ASA, San Francisco.

TAMAS, Pai (1993) "Inovacios teljesitmenyek es vallalati strategiak (Achievement in Innovation and Company Strategies).” Budapest: Institute for the Study of Social Conflicts, Working Paper.

WEICK, Karl E. (1977) “Organization Design: Organizations as Self-Designing Systems.” Organizational Dynamics 6(2):31-45. 